\title{
The Formation of Hemingway's Ecological Awareness
}

\author{
Ji Junjun ${ }^{1}$ \\ ${ }^{1}$ School of Continuing Education, Guagndong University of Foreign Studies, Guangzhou, China \\ Correspondence: Ji Junjun. Tel: 13678938486. E-mail: elaineji3000@126.com \\ Received: November 20, $2017 \quad$ Accepted: December 19, $2017 \quad$ Online Published: February 26, 2018 \\ doi:10.5539/ass.v14n3p10 \\ URL: https://doi.org/10.5539/ass.v14n3p10
}

\begin{abstract}
Hemingway, who has done a lot to shape twentieth-century American literature, remains an interesting writer because it is possible to read him in many ways. With the rise of American nature writing, the natural world in Hemingway's fiction has recently caught critical attention. This paper is going to explore the origin of his nature complex and ecological awareness from three aspects, that is, his life experience in nature, his reading experience and the influence of the painter Cezanne.
\end{abstract}

Keywords: Hemingway, nature, ecological awareness

\section{Introduction}

As Fleming points out in the introduction to Hemingway and the Natural World, "Few authors in history have been so closely identified with the natural world as Earnest Hemingway". Hemingway's sensitive to nature is apparent both in his life and in his writing. Being regarded as a man who puts a high value on sanitize or 'tonic' wildness, Hemingway admires wilderness for its own qualities and he often portrays the wilderness as a nurturing parent, knowing what is good for us. Wilderness bears something that is right, and something that we are missing. For him, nature is the spiritual healer. As told throughout Baker's biography, when Hemingway finished a book, he immediately escaped to the West or the Florida Keys, where he could recuperate. An obvious example from Hemingway's fiction is his short story "Big Two-Hearted River," when the war-torn Nick Adams finally finds at least some mental peace away from all humanity and in the presence of nature. In the heart of Hemingway, there is everlasting gratitude for the fishing and shooting. Hemingway shows us through the passion and physicality of his life that the marrow of life is to be found and lived outside.

As a lover of natural world, Hemingway was a deeply spiritual man in his attachments to place. A few months before he died, Hemingway told an interviewer, "to know and love nature is a simpler and higher thing than to know the geology of the rocks and the chemistry of trees" (Williams 14). Throughout his life, the memories of wild nature, the knowledge of wild nature, and his need for wild nature never left him, that was his gulf stream, in his blood, in the land and finally on the page. As demonstrated in For Whom the Bell Tolls, "It's very healthy in the open air" (11). Even when it snows heavily, Robert Jordan would like to sleep outside (173).

Hemingway's early experience in the natural surroundings and his later adventures and explorative life as a hunter and a fisherman in nature greatly affected his outlook about nature. With his travels in Europe, Africa, the Caribbean and the American west, Hemingway's concept of nature was expanded, so was his concept of how mankind related to nature expanded. In this article, I am going to probe into Hemingway's natural world to track down the formation of his ecological awareness.

The following part of this paper will explore the origin of Hemingway's nature complex and ecological awareness from three aspects, that is, his life experience in nature, his reading experience and the influence of the painter Cezanne.

\section{The Formation of Hemingway's Ecological Awareness}

\subsection{Hemingway's Life Experience in Nature}

Hemingway was born in July, 21, 1899. seven weeks later, he started his first journey to American wilderness. From then on, he had been pursuing the outdoor activities all his life. His father, Clarence Edmonds Hemingway, was interested in, apart from medicine, outdoor activities. he was a skilled hunter and fisherman. he loved food and the preparation of it and was equally at home in the woods and in the kitchen. in rare moments of response he dreamed of escaping to the wilds of Nevada or becoming a missionary in Guam (Kert 25-26). This passion for nature was passed on to Hemingway, his first-born son. Early in his childhood, Hemingway was introduced by 
his father into appreciation of nature. As a small child, he was taken every summer from his home in Oak Park to his parents' northern Michigan vacation property. There in the woods in prairies of northern Illinois, Hemingway would pursue the outdoor activities. From his youth he was taught how to camp, hunt, and fish, and he grew up with a persistent need to be in the wilds. In the unpublished chapter of Death in the Afternoon, Hemingway documents and laments over the lost of the real "heart" - the forest in northern Michigan (William 10-11). He was mentored by his paternal grandmother Adelaide and his father, who gave young Ernest an "ethic of place", not only a love of hunting but a reverence and respect for the hunted. It is a well-known story that Hemingway was lectured "on the needless destruction of harmless animals" when he and a friend killed a porcupine that had tangled with a neighbor's dog. According to Carlos Baker, "Having shot it...they were now obliged" to cook and eat the porcupine" (16). The lesson was obviously internalized as Hemingway later instructed his own young son Jack, "Never waste fish, Schatz, it's criminal to kill anything you aren't going to eat" (Jack 18). This respect for the proper use of nature is present in Hemingway's earliest writings. As he wrote to Bruce Bliven, "My father, my grandfather, and my great-grandfather were all hunters and fisherman and it is impossible for people who do not care to hunt or to fish to realize how those who do feel about it I have tried to be very honest about those feelings and to make good pictures of those things but people care very little for the truth" (qtd. in murphy, 171)

As a result, Hemingway's writing and correspondence reveal a man who was thoughtful about the animals he killed, a man who hunted and fished for a prey he loved and respected.

From his fiction to nonfiction, and even in his personal correspondence, Hemingway is concerned with the preservation of the natural world. In a 1936 letter to Maxwell Perkins, Hemingway wrote from the Nordquist Ranch in Wyoming that on a recent hunt for "Crizzles," he got two. "They were beautiful to meet in the timber that way...I could have killed the three I think but they were so damned handsome I was sorry I killed more than one but at the time did not have much time to decide" (Selected Letters 454). Mary Hemingway, in an interview with Dennis Brain, supports this view that the encounter is more important than killing numerous animals. "A great deal of the hunting was the pleasure of walking through African bush or Idaho sagebrush...It was certainly not killing that engaged him...we passed up a great many animals who were just too sweet to shoot" (Brian 291).There is a respect for animals in Hemingway, an admiration, and a sensitivity toward their suffering. In For Whom the Bell Tolls, Hemingway declares that the bear is man's brother (40). In "The Short Happy Life of Francis Macomb", Hemingway even employs the lion's point of view. As a hunter, Macomb is faulted because he doesn't stop to consider what the lion is thinking. Littless, in "The Last Good Country," feels sorry for the birds her brother has just shot because "They were enjoying the morning just like we were"(40).

The above facts demonstrate that, in spite of Hemingway's well-publicized enthusiasm for the challenge of the hunt, Hemingway clearly understand the relationship which allows a man to hunt and fish for a prey he loves, a relationship that eventually leads him to give his best efforts toward preserving intact the natural habits those species that need to survive. This sensitivity towards nature began with high school apprentice pieces set in the north woods. Short stories such as "Sepi Jingan" and "Judgement of Manitou," both of which appeared in his high school literary magazine Tabula, show the dual influence of his personal exposure to the forests and Native Americans of northern Michigan and of the works of Stewart Edward White and Owen Wiser. After his moves to France in 1921, he didn't become urbanized as expected. Instead, he continued to pursue the outdoor life, which was attested by articles on tuna fishing in Spain, trout fishing in Switzerland, hiking in Germany, skiing in Switzerland, and game shooting across the continent. Currently, hunting and fishing are regarded by some of as barbaric sports, and self-styled animal rights activist and friends of animals see these activities as diametrically opposed to the welfare of the fish and game on which they depend. But it is not the same with Hemingway.

For Hemingway, the desire to hunt is paradoxically compatible with love of wildlife. Hunting is a highly satisfying occupation for many persons because it calls into play a multiplicity of physical and mental attributes that appear to be woven in the human fabric" (Williams 8), which is demonstrated in his semi autobiographical character Nick Adams who is careful to release an unwanted trout he has caught only after wetting his hand to avoid disturbing the protective coating of the fish.

As Hemingway's world was enlarged by his travels in Europe, Africa, the Caribbean, and the American West, his concept of nature expanded to include sights, experiences, and activities. as his concept of the world changed, so did his concept of nature. The African animals had been part of his imaginative experience now become reality. New experiences, such as the corridors of Spain, expanded his concept of how mankind related to nature. Hemingway knew love and he knew it most deeply in his relationship to landscape. Just as Alfred Kazin points out in On Native Grounds, "No nature writer in all American literature save Thoreau has had Hemingway's sensitiveness to color, to climate, to the knowledge of physical energy under the heat or cold, that knowledge of the body thinking and moving through a landscape that Edmund Wilson, in another connection, has called 
Hemingway's 'barometric accuracy.' That accuracy was the joy of the huntsman and the artist" (Williams, 11)

Hemingway once writes: "Can no branch of natural History be studied without increasing that faith, love and hope, which we also, every one of us, need in out own journey through the wilderness of life" (Ibid), by which he reminds us not that we are conquerors of nature, but rather that we can be lovers, that the primordial forest does still exist and can offer us sustenance and safety.

\subsection{Hemingway's Reading Experience}

As the son of educated parents, young Hemingway did not confine himself to physical observation of the natural world but also approached nature through books. He owned a large number of natural history and travel books, including Teddy Roosevelt's 1902 The Deer Family and his 1910 African Game Trails (Reynolds, 177). During Ernest's formative years, he was greatly influenced by the articles and books of Theodore Roosevelt, who was the hero of the generation before World War I and of Hemingway's childhood and had also been taken up by the adventures of natural history from an early age (Reynolds, Young 25-26)

Beside Theodore Roosevelt's work, Hemingway also read many other travel books, ranging from copies of the American Rifleman and Field and Stream to colonel Townsend Wheelman's Wilderness Hunting and Wildcraft, from Harold Elmer Anthony's Field Book of North American Mammals ad Roger Tory Pererson's Field Gilde to the Birds to Loris Roule's Fishes, Their Journeys ad Migrations.

Upon moving to Key West, Florida, Hemingway became a noted big game fisherman. Once again, books supplemented his direct observation of nature. As Fleming records, he read Zane Grey, first to learn from him and later to compete with him. When Hemingway moved his book to Cuba in 1940, his luggage included three fishing books by the western writer.

As Terry Tempest Williams addressed at the seventh International Hemingway Conference," I was not surprised to find a complete set of field guides on the shelves of Hemingway 's home in Ketchum Peterson's field guides to butterflies, birds, mammals, reptiles, insects, ferns, wildflowers, trees, rocks and minerals, stars and planets" (Williams 12). With all those books at home, no wonder that Hemingway learned over 250 genus and species, the Latin names of the plants and animals of the Upper Peninsula in Michigan and the Midwestern United States.

"A real writer is studying everything all the time," Hemingway writes. No doubt this kind of bedrock knowledge contributed to his specificity, his insistence on accurate as well as impressionistic representation of landscape. If, as Gertrude Stein said, "Hemingway looked like a modern and smelled of museums" (216), he was also a hunter and fisherman, who smelled of libraries. The extensive reading results in the natural aura and influence of wildlands coursed through Hemingway's veins.

What's more, according to Reynold, Hemingway had borrowed Ambroise Vollards standard biography of Cezanne to learn his ideas about art, and most important of all, the way to "do" landscape, which is going to be expanded in the following part.

\subsection{Paul Cezanne's Influence}

Hemingway's love of art is well-known, especially his preference for Cezanne. In the article "Formal Analogies in the Texts and Paintings of Ernest Hemingway and Paul Cezanne", Thomas Hermann points out that "Hemingway claims to have learnt how to "do" landscapes from Cezanne... and the authors of several studies have so far acknowledges that similar impressions are evoked when reading a Hemingway text as when contemplating a picture by Cezanne." (Herman 29). It is true. As Terry Tempest Williams points out, "Hemingway studies Cezanne" (11). Between 1922nad 1924 he saw at least some 40 to 50 Cezanne in Paris. Several passages from fictional texts as well as from letters or interviews display the fascination Hemingway had for Cezanne's paintings, especially his landscapes. For example, in his letter to Gertrude Stein, he wrote: "I am trying to do the country like Cezanne" (Selected Letters 122); In the Nick Adam, it reads

"He was the greatest...He, Nick, wanted to write about country so it would be there like Cezanne had done it in painting. You had to do it from inside yourself. There wasn't any trick. Nobody had ever written about country like that. He felt almost holy about it. It was deadly serious. You could do it if you would fight it out" (239).

If we come back to Hemingway's statement that looking at paintings was "a part of learning to see, to hear, to think, to feel and to write," (qtd. In Murphy, 172), we might wonder what impact Cezanne's paintings could have had on Hemingway's writing.

First of all, Cezanne's paintings influence Hemingway's writing in terms of content. Early in 1850, the impressionists in France started to break with the rigid norms. With respect to content, there was a move away from mainly historic and religious themes toward landscape. Cezanne became more and more radical in his 
attempt to claim nature as the "supreme court" against which art had to be tested. He was convinced that the painter had to dedicate himself entirely to the study of nature (Herman 30-31). This perception of nature is embodied in Hemingway's writing, in which tonic wildness is put on a high value and nature plays a central role and makes a strong presence.

Secondly, Cezanne's paintings influence Hemingway's writing in terms of a sense of unity. Cezanne dreams of a unity, as Vollards put it: "Drawing and color are not separate, everything in nature being colored. During the process of painting, one draws; the more the color harmonizes, the more the drawing becomes precise. When the color has attained richness, the form has reached its plentitude" (Hermann 33).

As for Hemingway, "By rigorously subjecting all verbal or visual elements to the overall context, they create a sense of unity, and at the same time of openness, which forces the recipient to construct a meaning" (Hermann, 29). His landscape are comprised mainly of short descriptive sequences, which are mostly embedded in report, like in the sentence; "They walked down the hill across the fields and then turned to follow the river bank" (176) from "Out of Season". By frequently repeating key words like river, the landscapes are carefully constructed and win a strong presence in the story. The mixing of the narrative modes is part of the strategy to condense the context and helps to present the text as a compact unity.

Cezanne is often called the father of modern art. The strategies he developed in the second half of the nineteenth century in order to transport nature into art parallel to a great extent what the modernists tried to realize within literature in the $1920 \mathrm{~s}$.

Actually, the fact that Hemingway realized this parallel enabled him to create literary landscapes that belong to the best in twentieth century fiction. Hemingway has been a powerful mentor, in terms of what it means to create a landscape impressionistically on the page, to make it come alive, plus, breath, to "make the country so that you could walk into it" (A Movable Feast 91).

\section{Conclusion}

To sum up, Hemingway's life experience in nature, his reading experience and the influence from the painter Cezanne greatly contributed to Hemingway's ecological awareness, which made it possible for him to have presented before readers the marrow of human life found and lived outside in the natural world.

\section{References}

(1964) A Movable Feast. New York: Charles Scibner's Sons.

(1972) The Nick Adams Stories. New York: Charles Scibner's Sons.

(1981). Selected Letters, 1917-1961. Ed. Carlos Baker. New York: Charles Scibner's Sons.

(1986). The Young Hemingway. Oxford and New York: Basil Blackwell.

(1996). Out of Season. The Complete Stories of Earnest Hemingway. New York: Macmillan Publishing Company.

Baker, C. (1969). Ernest Hemingway. A Life Story. New York: Charles Scibner's Sons.

Brian, D. (1988). The True Gen. New York: Dell Publishing.

Fleming, E. R. (Ed.) (1999). Hemingway and the Natural World. Moscow and Idaho: University of Idaho Press.

Hemingway, E. (1995). For Whom the Bell Tolls, Simon \& Schuster Inc..

Herman, T. (1994). Formal Analogies in the Texts and Paintings of Earnest Hemingway and Paul Cezanne. Kenneth Rosen (Ed.). Hemingway Repossessed. Greenwood Publishing Group. Inc.

Kert, B. (1983). The Hemingway Women. New York and London: W.W. Norton \& Company, Inc.

Murphy, C. M. (1999). Hemingway's Gentle Hunters: Contradiction or duality? In R. E. Fleming (Ed.), Hemingway and the Natural World. Moscow and Idaho: University of Idaho Press.

Reynolds, M. S. (1981). Hemingway's Reading, 1910-1940. Princeton University Press. .

Williams, T. T. (1999). Hemingway and the Natural World. In R. E. Fleming (Ed.), Hemingway and the Natural World. Moscow, Idaho: University of Idaho Press.

\section{Copyrights}

Copyright for this article is retained by the author(s), with first publication rights granted to the journal.

This is an open-access article distributed under the terms and conditions of the Creative Commons Attribution license (http://creativecommons.org/licenses/by/4.0/). 